\title{
必要加速度ベクトルに基づいた，航空機の方位角・経路角制御の一方法*1
}

\section{A Heading and Flight-Path Angle Control of Aircraft Based on Required Acceleration Vector}

\author{
芳 谷 直 治*2 \\ Naoharu Yoshitani
}

Key Words : Flight Dynamics, Guidance and Control, Flight-Path Angle, Heading Angle, Acceleration Vector

\begin{abstract}
This paper describes a control of heading and flight-path angles of aircraft to time-varying command angles. The controller first calculates an acceleration command vector $\left(\vec{a}_{\mathrm{c}}^{\mathrm{V}}\right)$, which is vertical to the velocity vector. $\vec{a}_{\mathrm{c}}^{\mathrm{V}}$ consists of two components; the one is feedforward acceleration obtained from the rates of command angles, and the other is feedback acceleration obtained from angle deviations by using PID control law. A bank angle command around the velocity vector and commands of pitch and yaw rates are then obtained to generate the required acceleration. A roll rate command is calculated from bank angle deviation. Roll, pitch and yaw rate commands are put into the attitude controller, which can be composed of any suitable control laws such as PID control. The control requires neither aerodynamic coefficients nor online calculation of the inverse dynamics of the aircraft. A numerical simulation illustrates the effects of the control.
\end{abstract}

\section{記号の説明}

$\phi, \theta, \psi:$ ロール角, ピッチ角， ヨー角

$p, q, r:$ ロール角速度，ピツチ角速度，ヨ一角速度

$\alpha, \beta$ : 迎角，横滑り角

$\phi_{\mathrm{b}}$ : バンク角 (速度ベクトル回り)

$\lambda, \gamma$ : 進行方向の方位角 (上から見て時計回りが

正)，経路角 (上昇角)

$\vec{g}:$ 重力加速度ベクトル,$g=|\vec{g}|$

$\vec{V}_{\mathrm{a}}:$ 航空機速度ベクトル, $V_{\mathrm{a}}=\left|\vec{V}_{\mathrm{a}}\right|$

$x^{\mathrm{E}} y^{\mathrm{E}} z^{\mathrm{E}}$ 系 : 各軸が北，東，下を表わす静止座標系

$x^{\mathrm{B}} y^{\mathrm{B}} z^{\mathrm{B}}$ 系: 機体軸系

$x^{\mathrm{W}} y^{\mathrm{W}} z^{\mathrm{W}}$ 系: 風軸系

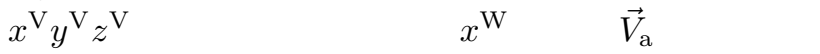
平右方向，および $x^{\mathrm{V}} y^{\mathrm{V}}$ 面に垂直下方向を 表わす座標系 (速度軸系)

$x^{\mathrm{C}} y^{\mathrm{C}} z^{\mathrm{C}}$ 系: 各軸が光れ攵れ，速度指令值ベクトル $\vec{V}_{\mathrm{ac}}$ の方向，水平右方向，および $x^{\mathrm{C}} y^{\mathrm{C}}$ 面に垂 直下方向を表わす座標系 (指令軸系)

$\vec{a}_{\mathrm{c}}^{\mathrm{V}}$ : 航空機加速度指令值ベクトル $\left(y^{\mathrm{V}} z^{\mathrm{V}}\right.$ 面内)

$(\cdot)_{\mathrm{c}}$ : 指令值

$(\cdot)^{\mathrm{T}}:$ ベクトルや行列の転置

$(\cdot)$ : 時間に関する微分

第 1 図に機体軸系, 速度ベクトルとおもな角度，角速度

\footnotetext{
*1 (C) 2004 日本航空宇宙学会

平成 15 年 10 月 9 日, 第 41 回飛行機シンポジウムにおいて発

表. 平成 15 年 10 月 2 日原稿受理
}

$* 2$ 帝京大学理工学部航空宇宙工学科
を示す．

$$
\text { 1. はじめに }
$$

無人機の自律飛行，および人間パイロットや管制官の負 荷低減のためには, 航空機を 3 次元空間内の目標方位や目 標経路に沿って自動的に飛行させる技術，すなわち自動方 位制御または自動経路制御の技術が必要である.このよう な制御技術については従来，いくつかの方法が提案されて (る1 ${ }^{14)}$.これらの方法はいずれも，航空機運動の逆システ ムを用いて舵面角度などの操作量を求めており, フィード バック制御では空力微係数などの值を必要とする.

本稿では, 航空機の方位角と経路角の制御において, 進 行方向に垂直な面内において航空機に必要な加速度べクト ルを加速度指令值としてまず求め, 乥れに基づいてロール， ピッチ, ヨーの角加速度指令值を算出して制御する方法に ついて述べる ${ }^{5)}$. 制御の基本的考え方は，必要な加速度を 適切なバンク角とピッチ角速度によって達成することであ る。制御系は階層構造になっていて, 上位の方位角・経路 角コントローラから下位の姿勢コントローラに指令值が送 られる.必要加速度べクトルは方位角と経路角の指令值変 化率とこれらの制御偏差とから求め, 時々刻々変化する指 令值への追従を可能としている.

航空機に必要な加速度に基づく制御方法は従来から提案 されているが, 従来法と比べて本制御方法は以下の特徵を 持つ.

P1 制御計算に航空機の逆システム (逆動力学) や空力微 係数を必要としない。

P2 迎角, 横滑り角，Gフォースの值の上下限制限を，ピッ 


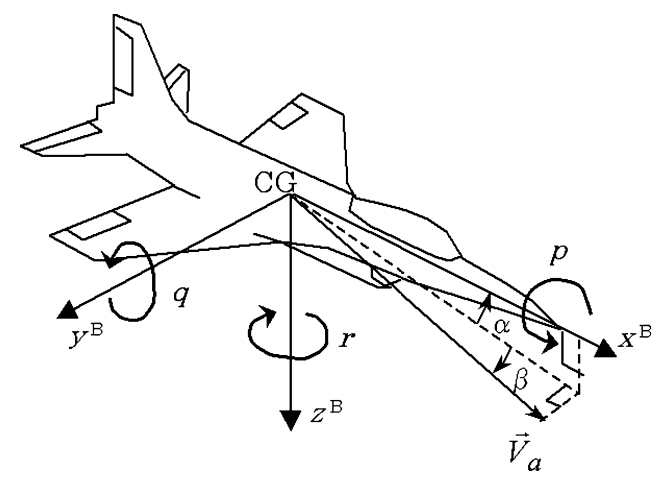

第 1 図 機体軸と速度, 角速度

チ角速度，ヨ一角速度の上下限制限や切替制御により 行う.

P3 種々の角度計算は, 球面幾何学の定理に基づいている ため, 姿勢角や進行方向制御偏差がどのような場合で も問題なく適用できる。

本制御が対象とする航空機は, エレベータ, エルロン, ラ ダーを制御舵面として備え, 運動性能が高く任意の姿勢角 を実現できる戦闘機や曲技機とするが，姿勢角などに制限 を設ければ，一般の航空機にも適用可能と思われる。

\section{2. 制 御 方 法}

制御系のブロック線図を第 2 図に示す．制御系は階層構 造をしており, 上位の Controller \#1 (方位角・経路角コ ントローラ) では, 方位角 $\lambda$ と経路角 $\gamma$ が光れらの指令值 に追従するように, 必要加速度べクトルをまず算出し, 光 れに基づいてロール，ピッチ，ヨーの角速度指令值 $p_{\mathrm{c}}, q_{\mathrm{c}}$ ， $r_{\mathrm{c}}$ を求め, 速度指令值 $V_{\mathrm{ac}}$ とともに出力する.

つぎに下位の Controller \#2 (姿勢・速度コントローラ) では, エルロン・エレベータ・ラダーを操作して $p, q, r$ を，エンジン出力を操作して $V_{\mathrm{a}}$ を㚇れ光れ制御する。

以下に方位角・経路角コントローラでの制御アルゴリズ ムを示す. 第 2 図において , このコントローラへの入力の 值 (現在値) は既知とする.

2.1 進行方向制御偏差の算出 各座標系の原点を共通 原点 $\mathrm{O}$ として, $\mathrm{O}$ を中心に半径 1 の球面を考えた图を，第 3 図に示す . 原点から見たときの方位は球面上の点で表わさ れる.この球面上での航空機進行方向の制御偏差，すなわ ちベクトル $\vec{V}_{\mathrm{ac}}, \vec{V}_{\mathrm{a}}$ の始点をともに原点としたときの, 各 ベクトルと球面との交点の差を調べる. 球面と $z^{\mathrm{E}}$ 軸負方 向 (上方向)， $\vec{V}_{\mathrm{a}} ， \vec{V}_{\mathrm{ac}}$ との交点を兴れ光れ $\mathrm{U}, \mathrm{V}, \mathrm{C}$ とす る. 球面三角形 VUC において， $\angle \mathrm{VUC}, \angle \mathrm{UCV}, \angle \mathrm{UVC}$

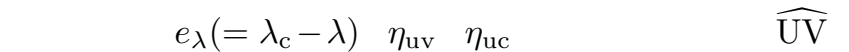
$\widehat{\mathrm{UC}}, \widehat{\mathrm{VC}}$ の長さ (原点となす角度) を光れ光れ $\gamma_{1}, \gamma_{\mathrm{c} 1}$ ， $e_{\mathrm{v}}$ とおく.ここで, $0 \leq e_{\mathrm{v}} \leq \pi,-\pi \leq \eta_{\mathrm{uv}}, \eta_{\mathrm{uc}} \leq \pi$ と し， $\eta_{\mathrm{uv}}, \eta_{\mathrm{uc}}$ は図の向きを正とする.

さて求める制御偏差の大きさは $e_{\mathrm{v}}$, 方向は $\eta_{\mathrm{uc}}$ で表わ される.これらを既知の值 $\gamma, \gamma_{\mathrm{c}}, e_{\lambda}$ により表わすことを 考える.まず図より明らかに

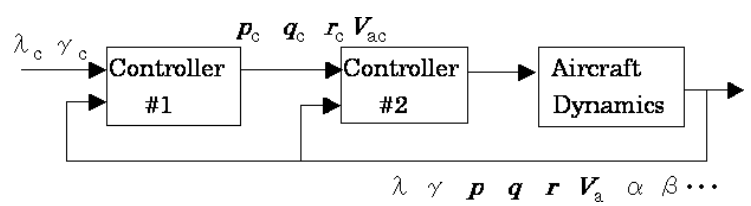

第 2 図 制御系ブロック線図

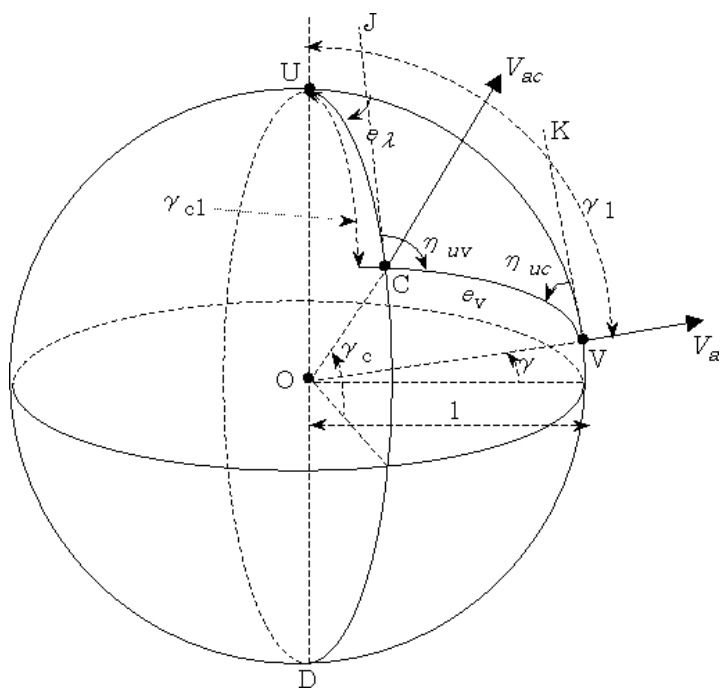

第3図 進行方向制御偏差

$$
\begin{aligned}
& \gamma_{1}=\frac{\pi}{2}-\gamma[\mathrm{rad}], \quad \sin \gamma_{1} \geq 0 \\
& \gamma_{\mathrm{c} 1}=\frac{\pi}{2}-\gamma_{c}[\mathrm{rad}], \quad \sin \gamma_{\mathrm{c} 1} \geq 0
\end{aligned}
$$

一方，球面三角形の定理より次式が成り立つ ${ }^{6)}$ 。

$$
\begin{aligned}
& \cos e_{\mathrm{v}}=\cos \gamma_{1} \cos \gamma_{\mathrm{c} 1}+\sin \gamma_{1} \sin \gamma_{\mathrm{c} 1} \cos e_{\lambda} \\
& \cos \gamma_{\mathrm{c} 1}=\cos \gamma_{1} \cos e_{\mathrm{v}}+\sin \gamma_{1} \sin e_{\mathrm{v}} \cos \eta_{\mathrm{uc}} \\
& \cos \gamma_{1}=\cos \gamma_{\mathrm{c} 1} \cos e_{\mathrm{v}}+\sin \gamma_{\mathrm{c} 1} \sin e_{\mathrm{v}} \cos \eta_{\mathrm{uv}} \\
& \frac{\sin \eta_{\mathrm{uc}}}{\sin \gamma_{\mathrm{c} 1}}=\frac{\sin \eta_{\mathrm{uv}}}{\sin \gamma_{1}}=\frac{\sin e_{\lambda}}{\sin e_{\mathrm{v}}}, \quad\left(\sin e_{\mathrm{v}}>0\right) \\
& \eta_{\mathrm{uc}}=\eta_{\mathrm{uv}}= \pm \frac{\pi}{2}[\mathrm{rad}], \quad\left(\sin e_{\mathrm{v}}=0\right)
\end{aligned}
$$

(3) 式右辺の值を $c_{\mathrm{ev}}$ とする . この值は既知の值から求 められ， $0 \leq e_{\mathrm{v}} \leq \pi$ を考慮すると

$$
e_{\mathrm{v}}=\arccos c_{\mathrm{ev}}[\mathrm{rad}]
$$

となる .

つぎに $\sin e_{\mathrm{v}}>0$ のときの $\eta_{\mathrm{uc}}, \eta_{\mathrm{uv}}$ の值を求める . ま ず $e_{\lambda}, e_{\mathrm{v}}$ から (6) 式右辺の值を求め, これを $s_{\lambda \mathrm{v}}$ とす る. (4) 式右辺第 2 項の符号は $\cos \eta_{\mathrm{uc}}$ および $\left(\cos \gamma_{\mathrm{c} 1}-\right.$ $\left.\cos \gamma_{1} \cos e_{\mathrm{v}}\right)$ の符号と一致する . したがって (6) 式より次 式か導かれる.

$$
\eta_{\mathrm{uc}}=\left\{\begin{array}{c}
\arcsin \left(s_{\lambda \mathrm{v}} \sin \gamma_{\mathrm{c} 1}\right)[\mathrm{rad}], \\
\left(\cos \gamma_{\mathrm{c} 1} \geq \cos \gamma_{1} \cos e_{\mathrm{v}},\right. \\
\text { すなわち } \left.\cos \eta_{\mathrm{uc}} \geq 0\right) \\
\pi-\arcsin \left(s_{\lambda \mathrm{v}} \sin \gamma_{\mathrm{c} 1}\right)[\mathrm{rad}], \\
\left(\cos \gamma_{\mathrm{c} 1}<\cos \gamma_{1} \cos e_{\mathrm{v}},\right. \\
\text { すなわち } \left.\cos \eta_{\mathrm{uc}}<0\right)
\end{array}\right.
$$


同樣にして $\eta_{\mathrm{uv}}$ の值も次式で求められる.

$$
\eta_{\mathrm{uv}}=\left\{\begin{array}{c}
\arcsin \left(s_{\lambda \mathrm{v}} \sin \gamma_{1}\right)[\mathrm{rad}], \\
\left(\cos \gamma_{1} \geq \cos \gamma_{\mathrm{c} 1} \cos e_{\mathrm{v}}\right) \\
\pi-\arcsin \left(s_{\lambda \mathrm{v}} \sin \gamma_{1}\right)[\mathrm{rad}], \\
\left(\cos \gamma_{1}<\cos \gamma_{\mathrm{c} 1} \cos e_{\mathrm{v}}\right)
\end{array}\right.
$$

計算の結果 , $\eta_{\mathrm{uc}}$ や $\eta_{\mathrm{uv}}$ の值が $\pi$ より大きくなったとき は, $2 \pi$ を減算する。

以上の結果を用いて進行方向制御偏差を, $y^{\mathrm{V}} z \mathrm{~V}$ 面内のべ クトル $\vec{e}_{\mathrm{v}}^{\mathrm{V}}$ で表わす. $\vec{e}_{\mathrm{v}}^{\mathrm{V}}$ は $\left(y^{\mathrm{V}},-z^{\mathrm{V}}\right)$ 成分 $\left[\begin{array}{ll}e_{\mathrm{v} y}^{\mathrm{V}} & e_{\mathrm{v}-z}^{\mathrm{V}}\end{array}\right]^{\mathrm{T}}$ によりつぎのように定義する .

$$
\vec{e}_{\mathrm{v}}^{\mathrm{V}}=\left[\begin{array}{ll}
e_{\mathrm{v}} \sin \eta_{\mathrm{uc}} & e_{\mathrm{v}} \cos \eta_{\mathrm{uc}}
\end{array}\right]^{\mathrm{T}}
$$

以下, $y^{\mathrm{V}} z^{\mathrm{V}}$ 面, $y^{\mathrm{W}} z^{\mathrm{W}}$ 面, $y^{\mathrm{C}} z^{\mathrm{C}}$ 面など, 第 3 図の球面 への接平面内におけるべクトルは, 上式のように各座標系 の $(y,-z)$ 成分で表わすことにし，"V"，"W"，"C"など で座標系を表わす．

2.2 航空機に必要な加速度の算出 制御計算では, $y^{\mathrm{V}} z^{\mathrm{V}}$ 面内て航空機に必要な加速度のベクトル $\vec{a}_{\mathrm{c}}^{\mathrm{V}} の\left(y^{\mathrm{V}},-z^{\mathrm{V}}\right)$ 方向成分 $\left[\begin{array}{ll}a_{\mathrm{c} y}^{\mathrm{V}} & a_{\mathrm{c}-z}^{\mathrm{V}}\end{array}\right]^{\mathrm{T}}$ を求める. $\vec{a}_{\mathrm{c}}^{\mathrm{V}}$ は次式で表わされる.

$$
\begin{aligned}
\vec{a}_{\mathrm{c}}^{\mathrm{V}} & =\left[\begin{array}{ll}
a_{\mathrm{c} y}^{\mathrm{V}} & a_{\mathrm{c}-z}^{\mathrm{V}}
\end{array}\right]^{\mathrm{T}} \\
& =\left[\begin{array}{ll}
\left(a_{\mathrm{ff} y}^{\mathrm{V}}+a_{\mathrm{fb} y}^{\mathrm{V}}\right) & \left(a_{\mathrm{ff}-z}^{\mathrm{V}}+a_{\mathrm{fb}-z}^{\mathrm{V}}\right)
\end{array}\right]^{\mathrm{T}}
\end{aligned}
$$

下添え字 “ff” はフィードフォワード成分を，"fb”はフィー ドバック成分を表わす．

2.2.1 フィードフォワード成分の計算 フィードフォワー ド成分を表わすべクトル $\vec{a}_{\mathrm{ff}}^{\mathrm{V}}=\left[\begin{array}{ll}a_{\mathrm{ff} y}^{\mathrm{V}} & a_{\mathrm{ff}-z}^{\mathrm{V}}\end{array}\right]^{\mathrm{T}}$ は, 目標方 向 $\left[\begin{array}{ll}\lambda_{c} & \gamma_{c}\end{array}\right]^{\mathrm{T}}$ の変化率に基づいて定める . この变化率を $\left(y^{\mathrm{C}},-z^{\mathrm{C}}\right)$ 成分で表わしたべクトルを $\vec{\xi}^{\mathrm{C}}\left(=\left[\begin{array}{ll}\xi_{y}^{\mathrm{C}} & \xi_{-z}^{\mathrm{C}}\end{array}\right]^{\mathrm{T}}\right)$ とおくと, $\vec{\xi}^{\mathrm{C}}$ は, 単位速度指令べクトル $\vec{V}_{\mathrm{ac}} /\left|\vec{V}_{\mathrm{ac}}\right|$ の回転 によって生じる加速度べクトルと見なすことができ，

$$
\vec{\xi}^{\mathrm{C}}=\left[\begin{array}{ll}
\dot{\lambda}_{\mathrm{c}} \sin \gamma_{\mathrm{c} 1} & \dot{\gamma}_{\mathrm{c}}
\end{array}\right]^{\mathrm{T}}
$$

と表わされる .

一方，求める $\vec{a}_{\mathrm{ff}}^{\mathrm{V}}$ は $y^{\mathrm{V}} z^{\mathrm{V}}$ 面内ベクトルだから， $\vec{\xi}^{\mathrm{C}}$ も $y^{\mathrm{V}} z^{\mathrm{V}}$ 面内ベクトルに变換する必要がある。 $\left(y^{\mathrm{V}},-z^{\mathrm{V}}\right)$ 成 分で表わした変換後のベクトルを $\vec{\xi}^{\mathrm{V}}\left(=\left[\begin{array}{ll}\xi_{y}^{\mathrm{V}} & \xi_{-z}^{\mathrm{V}}\end{array}\right]^{\mathrm{T}}\right)$ と し, $\vec{\xi}^{\mathrm{C}}$ から $\vec{\xi}^{\mathrm{V}}$ への変換は, 球面上における $z^{\mathrm{C}}$ 軸と $z^{\mathrm{V}}$ 軸との角度差 $\tau^{\mathrm{CV}}$ だけ座標軸を回転させることによって 行うものとする .

従来の経路制御方法では, 本節と同樣の考え方により, 航 空機加速度目標値のフィードフォワード成分を目標の変化 率から求めているが, 航空機進行方向は目標方向とほぼ同 じ $\left(\tau^{\mathrm{CV}}=0\right)$ と仮定している.目標方向制御偏差 $e_{\mathrm{v}}$ が小 さく，かつ $\gamma, \gamma_{\mathrm{c}}$ ともに $\pm \pi / 2[\mathrm{rad}]$ に近くないとの条件 のもとでは, $\tau^{\mathrm{CV}}=0$ と見なして差し支えないが，この条 件が成り立たない場合は誤差が大きくなるため， $\tau^{\mathrm{CV}}$ の考 慮が必要である。

$\tau^{\mathrm{CV}}$ はつぎのようにして求める.まず第 3 図において , 点 $\mathrm{C}$ における $-z^{\mathrm{C}}$ 方向 (上方向) 直線を直線 $\mathrm{CJ}$, 点 $\mathrm{V}$
における $-z^{\mathrm{V}}$ 方向直線を直線 $\mathrm{VK}$ とする．つぎに直線 $\mathrm{CJ}$ を, 点 $\mathrm{O}$ を通り平面 $\mathrm{COV}$ に垂直な直線を回転軸として， 点 $\mathrm{C}$ が点 $\mathrm{V}$ に一致するまで回転する .このときの $\angle \mathrm{JVK}$ が $\tau^{\mathrm{CV}}$ であり, 角度の正方向は点 $\mathrm{O}$ から見て時計回り方 向とする.図より

$$
\tau^{\mathrm{CV}}=\pi-\eta_{\mathrm{uv}}-\eta_{\mathrm{uc}}[\mathrm{rad}]
$$

である

$\tau^{\mathrm{CV}}$ を用いて, 変換の式は次式で表わされる.

$$
\begin{aligned}
& {\left[\begin{array}{c}
\xi_{y}^{\mathrm{V}} \\
\xi_{-z}^{\mathrm{V}}
\end{array}\right]=\boldsymbol{T}_{\mathbf{r}}\left(\tau^{\mathrm{CV}}\right)\left[\begin{array}{c}
\xi_{y}^{\mathrm{C}} \\
\xi_{-z}^{\mathrm{C}}
\end{array}\right]} \\
& \boldsymbol{T}_{\mathbf{r}}\left(\tau^{\mathrm{CV}}\right)=\left[\begin{array}{cc}
\cos \tau^{\mathrm{CV}} & -\sin \tau^{\mathrm{CV}} \\
\sin \tau^{\mathrm{CV}} & \cos \tau^{\mathrm{CV}}
\end{array}\right]
\end{aligned}
$$

ここで $\boldsymbol{T}_{\mathbf{r}}(\tau)$ は，座標系を任意の角度 $\tau[\mathrm{rad}]$ だけ回転さ せるための变換行列である .

$\vec{a}_{\mathrm{ff}}^{\mathrm{V}}$ は $\vec{\xi}^{\mathrm{V}}$ に比例させるとともに，進行方向制御偏差 $e_{\mathrm{v}}$ が大きいときは, $e_{\mathrm{v}}$ を小さくすることを優先させるために， 後述のフィードバック成分 $\vec{a}_{\mathrm{fb}}^{\mathrm{V}}$ に比べて $\vec{a}_{\mathrm{ff}}^{\mathrm{V}}$ を小さくする ことか望ましい，乥こで $\vec{a}_{\mathrm{ff}}^{\mathrm{V}}$ を次式で表わすことにする．

$$
\vec{a}_{\mathrm{ff}}^{\mathrm{V}}= \begin{cases}\vec{\xi}^{\mathrm{V}} V_{\mathrm{a}} \cos e_{\mathrm{v}}, & e_{\mathrm{v}}<\pi / 2 \\ \mathbf{0}, & e_{\mathrm{v}} \geq \pi / 2\end{cases}
$$

$\cos e_{\mathrm{v}}$ は, $e_{\mathrm{v}}$ が大きいほど $\left|\vec{a}_{\mathrm{ff}}^{\mathrm{V}}\right|$ を小さくするために導入 した .なお，上式で $V_{\mathrm{a}}$ の代わりに $V_{\mathrm{ac}}$ を用いると，空間 経路の曲率に相当する $\left|\vec{a}_{\mathrm{ff}}^{\mathrm{V}}\right| / V_{\mathrm{a}}$ の值が $\left(V_{\mathrm{ac}} / V_{\mathrm{a}}\right)$ に依存し て変化し，好ましくない．

2.2.2 フィードバック成分の計算 フィードバック成分 を表わすべクトル $\vec{a}_{\mathrm{fb}}^{\mathrm{V}}=\left[\begin{array}{ll}a_{\mathrm{fb} y}^{\mathrm{V}} & a_{\mathrm{fb}-z}^{\mathrm{V}}\end{array}\right]^{\mathrm{T}}$ の計算法を述べ る.フィードバック制御則には種々の方式を適用可能であ り，ここでは実用上最も普及している PID（比例・積分・ 微分) 制御則を用いる.

積分制御のために，制御扁差べクトル $\vec{e}_{\mathrm{v}}^{\mathrm{V}}$ を制御周期 $\Delta T$ ごとに積算したべクトル $\vec{S}_{\mathrm{e}}^{\mathrm{V}}$ を導入する. $\vec{S}_{\mathrm{e}}^{\mathrm{V}}$ は $\left(y^{\mathrm{V}},-z^{\mathrm{V}}\right)$ 成分で表わされるから， $\Delta T$ の間に $y^{\mathrm{V}}, z^{\mathrm{V}}$ 軸が回転 (球 面上で方向変化) する場合はこれを考慮する必要がある.こ の方向変化について以下に検討する .

第 4 図は第 3 图と同樣の球面を表わす.まず $\Delta T$ だけ前 の $x^{\mathrm{V}}, z^{\mathrm{V}}$ 軸を兰れ光れ $x_{(-1)}^{\mathrm{V}}, z_{(-1)}^{\mathrm{V}}$ 軸とし, $x_{(-1)}^{\mathrm{V}}$ 軸 と第 4 図の球面との交点を $\mathrm{F}$, 点 $\mathrm{F}$ における $-z_{(-1)}^{\mathrm{V}}$ 軸方 向直線を直線 $\mathrm{FG}$, 点 $\mathrm{V}$ における $-z^{\mathrm{V}}$ 軸方向直線を 2.2 .1 節の場合と同じく直線 VK とする．

つぎに, 点 $\mathrm{F}$ を球面上で点 $\mathrm{U}$ の方向に $\Delta \gamma$ だけ移動し た点を $\mathrm{P}, \mathrm{P}$ における接平面上で上方向 $\left(-z_{(-1)}^{\mathrm{V}}\right.$ 軸方向) 直線を直線 $\mathrm{PQ}$ とする. 点 $\mathrm{P}$ と点 $\mathrm{V}$ とは方位角が $\Delta \lambda$ だ け異なり, 経路角 (水平面からの角度) は同じである．し たがって $\gamma \neq 0$ のとき直線 $\mathrm{PQ}$ と直線 VK とは 1 点で交 わり, 弚の交点を $\mathrm{R}$ とする.

ここで $\Delta \lambda=0$, すなわち 2 点 $\mathrm{P}, \mathrm{V}$ が一致している場 合, $y^{\mathrm{V}}$ または $z^{\mathrm{V}}$ 軸の「球面上における $\Delta T$ 間の方向変 


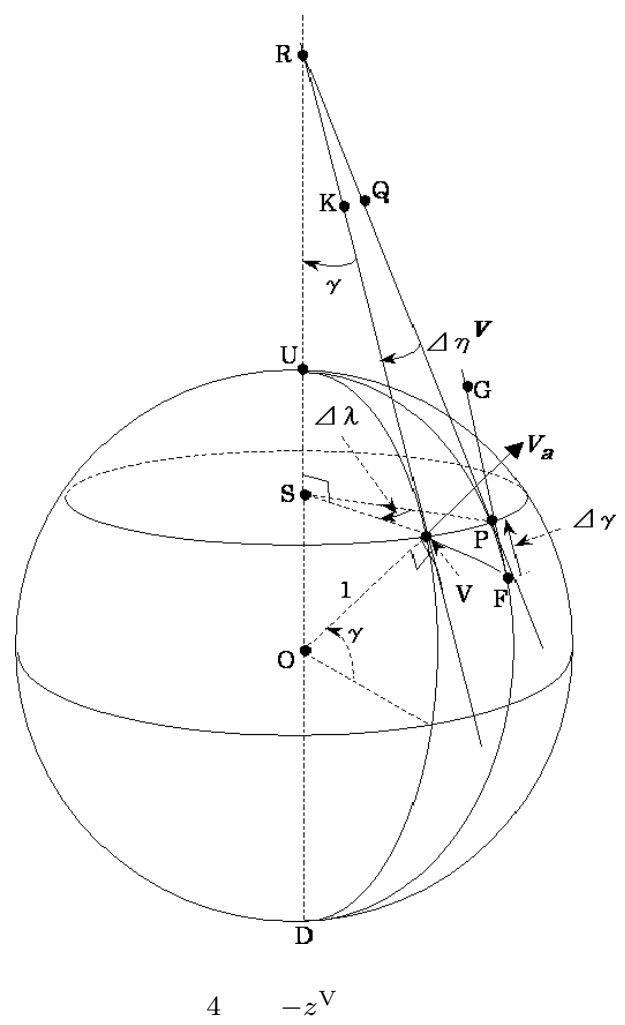

化 (方向差)」はないが, $\gamma \neq 0$ かつ $\Delta \lambda \neq 0$ の場合は， 方向差が生じる.この「球面上における方向差」は一般に つぎのように定義する。

接平面上ベクトルの球面上における方向差の定義 : 第 4 図の球面上の任意の 2 点 $\mathrm{M}, \mathrm{N}$ における各接平面上におい て， M, N を始点とした任意方向のベクトル $\vec{m}, \vec{n}$ を考え る. 2 点 $\mathrm{M}, \mathrm{N}$ を通る球面上の大円と, $\vec{m}, \vec{n}$ とのなす角 度を弚れ光れ $\mu, \nu$ としたとき, ベクトル $\vec{m}, \vec{n}$ の球面上 における方向差 (角度差) を， $\mu$ と $\nu$ の差で定義する。

時間 $\Delta T$ の間の $y^{\mathrm{V}}$ または $z^{\mathrm{V}}$ 軸の球面上での方向変 化，すなわち回転の角度を $\Delta \eta^{\mathrm{V}}$ と表わし， $\Delta T$ 間の $\lambda$ と

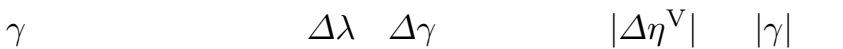
大きいほど大きい .

$\Delta \eta^{\mathrm{V}}$ は, 2.2 .1 節の $\tau^{\mathrm{CV}}$ と同樣にして , 第 4 図でつぎ のように定義される.まず直線 $\mathrm{FG}$ を, 点 $\mathrm{O}$ を通り平面 FOV に垂直な直線を回転軸として, 点 $\mathrm{F}$ が点 $\mathrm{V}$ に一致す るまで回転する .このときの $\angle \mathrm{GVK}$ が $\Delta \eta^{\mathrm{V}}$ である . 角 度の正方向は, 点 $\mathrm{O}$ から見て時計回りの方向とする.

$\Delta \gamma$ は小さいので $\Delta \eta^{\mathrm{V}}$ は $\Delta \gamma$ には依存せず，

$$
\Delta \eta^{\mathrm{V}} \simeq-\Delta \lambda \cdot \sin \gamma
$$

と表わされる .

(18) 式の導出 : 第 4 図において大円の弧 $\widehat{\mathrm{FV}}$ の長さは 小さいから, 球面三角形 FPV はほぼ平面と見なすことが できる .このとき $\angle \mathrm{PRV}$ は $\Delta \eta^{\mathrm{V}}$ にほぼ等しい . したがっ て $\gamma \neq 0$ のとき次式が成り立つ.

$$
\overline{\mathrm{PV}}=2 \overline{\mathrm{VR}} \sin \frac{\left|\Delta \eta^{\mathrm{V}}\right|}{2}=2 \overline{\mathrm{SV}} \sin \frac{|\Delta \lambda|}{2}
$$

ここで，

$$
\overline{\mathrm{VR}}=\frac{\overline{\mathrm{SV}}}{\sin \gamma}
$$

1) $\cos \gamma$ が 1 末満で 0 に近くないとき: $\widehat{\mathrm{PV}} \simeq|\Delta \lambda|$. $\cos \gamma \ll 1$ より $|\Delta \lambda| \ll 1$ が成立 . $\left|\Delta \eta^{\mathrm{V}}\right| \leq|\Delta \lambda|$ を考慮 すると次式が成り立つ .

$$
\sin \frac{\left|\Delta \eta^{\mathrm{V}}\right|}{2} \simeq \frac{\left|\Delta \eta^{\mathrm{V}}\right|}{2}, \quad \sin \frac{|\Delta \lambda|}{2} \simeq \frac{|\Delta \lambda|}{2}
$$

(19) (21) 式から (18) 式が導かれる .

注) $\Delta \eta^{\mathrm{V}}$ と $\Delta \lambda$ は， $\gamma>0$ のとき異符号， $\gamma<0$ のと き同符号となる (第 4 図参照).

2) $\cos \gamma$ が 0 に近いとき: $\sin \gamma \simeq \pm 1$ だから (19)，(20) 式より $\left|\Delta \eta^{\mathrm{V}}\right|=|\Delta \lambda|$ となり，このときも (18) 式が導か れる。

3) $\gamma=0$ のとき : 明らかに $\Delta \eta^{\mathrm{V}}=0$ であり，(18) 式が 成り立つ。

現時点より $\Delta T$ だけ前の $\vec{S}_{\mathrm{e}}^{\mathrm{V}}$ の値を $\vec{S}_{\mathrm{e}(-1)}^{\mathrm{V}}$ とすると， $\vec{S}_{\mathrm{e}(-1)}^{\mathrm{V}}$ を現時点の $\left(y^{\mathrm{V}},-z^{\mathrm{V}}\right)$ 成分で表わすには, 座標系 を角度 $\Delta \eta^{\mathrm{V}}$ だけ回転させる必要がある.したがって $\vec{S}_{\mathrm{e}}^{\mathrm{V}}$ の更新は次式で表わされる .

$$
\vec{S}_{\mathrm{e}}^{\mathrm{V}}=\boldsymbol{T}_{\mathrm{r}}\left(\Delta \eta^{\mathrm{V}}\right) \cdot \vec{S}_{\mathrm{e}(-1)}^{\mathrm{V}}+\vec{e}_{\mathrm{v}}^{\mathrm{V}} \cdot \Delta T
$$

なお，後述の上下限制限によりピッチ等の角速度の指令 值が修正されたときは, 積分のワインドアップ防止のため に, 上式の右辺第 2 項は 0 にする .

$\vec{a}_{\mathrm{fb}}^{\mathrm{V}}$ は，この制御偏差に対する PID 制御の操作量として 次式で求める.

$$
\vec{a}_{\mathrm{fb}}^{\mathrm{V}}=V_{\mathrm{a}}\left(K_{\mathrm{aP}} \cdot \vec{e}_{\mathrm{v}}^{\mathrm{V}}+K_{\mathrm{aI}} \cdot \vec{S}_{\mathrm{e}}^{\mathrm{V}}+K_{\mathrm{aD}} \cdot \dot{\vec{e}}_{\mathrm{v}}^{\mathrm{V}}\right)
$$

ここで $K_{\mathrm{aP}}, K_{\mathrm{aI}}, K_{\mathrm{aD}}$ は制御ゲインであり，適当な定数 に定める .

以下, 第 2 図の Controller \# 2 への指令值の計算方法を 述べる。

2.3 バンク角 $\phi_{\mathrm{b}}$ とその指令值 $\phi_{\mathrm{bc}}$ の算出 $x^{\mathrm{V}}$ 軸回 りのバンク角 $\phi_{\mathrm{b}}$ は, $y^{\mathrm{V}} z^{\mathrm{V}}$ 平面内で揚力の方向を表わす。 迎え角 $\alpha$ が大きくなく，かつ, ピッチ角 $\theta$ が $\pm \pi / 2[\mathrm{rad}]$ に近くないとの条件のもとでは, $\phi_{\mathrm{b}}$ はロール角 $\phi$ に等し いと見なして差し支えないが, 上の条件が成り立たないと きは $\phi_{\mathrm{b}}$ を正しく求める必要がある .

注) ロール角 $\phi$ とバンク角 $\phi_{\mathrm{b}}$ : 迎角 $\alpha \neq 0$ でピッチ角 $\theta$ が $\pm \pi / 2[\mathrm{rad}]$ に近いときは, $x^{\mathrm{B}}$ 軸 (機体軸) と $x^{\mathrm{V}}$ 軸 (速度軸) の方向が, 方位角 (水平面上への正射影の方向) で最大 $\pi[\mathrm{rad}]$ 異なる場合も生じる . $\phi$ は $x^{\mathrm{B}}$ 軸回りの回 転角, $\phi_{\mathrm{b}}$ は $x^{\mathrm{V}}$ 軸回りの回転角なので, このとき $\phi$ と $\phi_{\mathrm{b}}$ も最大で $\pi[\mathrm{rad}]$ 異なる .

従来文献には $\phi_{\mathrm{b}}$ の求め方はほとんど記載されていない 


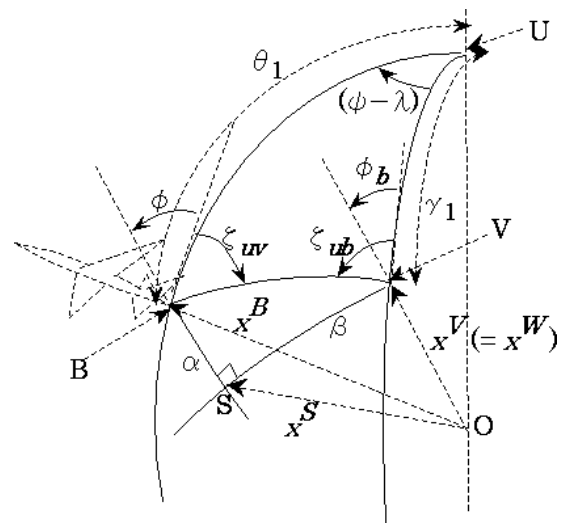

第 5 図 ロール角 $\phi$ とバンク角 $\phi \mathrm{b}$

ので，以下に光れを記す．

第 3 図と同樣な球面を第 5 図に示す. 図において, 点 $O$, $\mathrm{U}, \mathrm{V}$ は第 3 図と同樣であり, 点 $\mathrm{B}$ は, 点 $\mathrm{O}$ を原点とした ときの機体軸 $x^{\mathrm{B}}$ と球面との交点を, 点 $\mathrm{S}$ は, 安定軸 $x^{\mathrm{S}}$ と 球面との交点を表わす. $、$ 一角を $\psi$ とすると, 球面三角形 UBV において， $\angle \mathrm{VUB}$ は $(\psi-\lambda)$ であり，また $\angle \mathrm{UVB} ，$ $\angle \mathrm{UBV}$ は光れ光れ，図のように $\zeta_{\mathrm{ub}} ， \zeta_{\mathrm{uv}}$ と表わす.第 3 図と同樣に $-\pi \leq \zeta_{\mathrm{ub}}, \zeta_{\mathrm{uv}} \leq \pi$ とし， $\zeta_{\mathrm{ub}} ， \zeta_{\mathrm{uv}}$ は図の方 向を正とする .

$\gamma_{1}$ は第 3 図と同樣であり， $\theta_{1}=(\pi / 2)-\theta$ である .

第 5 図において, 点 $\mathrm{O}$ を通り平面 $\mathrm{OBV}$ に垂直な直線を 軸として，点 $\mathrm{B}$ が点 $\mathrm{V}$ に一致するまで機体を回転させる と, 回転後の機体の $x^{\mathrm{V}}$ 軸回り回転角がバンク角 $\phi_{\mathrm{b}}$ であ る.したがって，

$$
\phi_{\mathrm{b}}=\phi+\zeta_{\mathrm{ub}}+\zeta_{\mathrm{uv}}-\pi[\mathrm{rad}]
$$

となる $. \zeta_{\mathrm{ub}}, \zeta_{\mathrm{uv}}$ の值は, 第 3 図の $\eta_{\mathrm{uc}}, \eta_{\mathrm{uv}}$ の場合と同 樣にして求められる.

つぎにバンク角指令值 $\phi_{\mathrm{bc}}$ の算出方法を示す.重力加速度 ベクトル $\vec{g} の\left(y^{\mathrm{V}},-z^{\mathrm{V}}\right)$ 成分は $\left[\begin{array}{ll}0 & -g \cos \gamma\end{array}\right]$ と表わされ る.一方, 必要加速度 $\vec{a}_{\mathrm{c}}^{\mathrm{V}}$ に重力相殺ベクトル $\left[\begin{array}{ll}0 & g \cos \gamma\end{array}\right]^{\mathrm{T}}$ を加えたベクトルを $\vec{a}_{\mathrm{c} g}^{\mathrm{V}}$ とすると，

$$
\vec{a}_{\mathrm{c} g}^{\mathrm{V}}=\left[\begin{array}{ll}
a_{\mathrm{c} y}^{\mathrm{V}} & \left(a_{\mathrm{c}-z}^{\mathrm{V}}+g \cos \gamma\right.
\end{array}\right]^{\mathrm{T}}
$$

である.さて $\phi_{\mathrm{bc}}$ を求めるための基本的考え方は，文献 1〜3) と同樣に, 前節で求めた必要加速度 $\vec{a}_{\mathrm{c}}^{\mathrm{V}}$ を, ピッチ 角速度による揚力方向 $\left(-z^{\mathrm{W}}\right.$ 方向) 加速度で達成するこ とである. 兴のためには，バンク角 $\phi_{\mathrm{b}}$ を変化させて揚力 方向を $\vec{a}_{\mathrm{c} g}^{\mathrm{V}}$ の方向に向ける必要がある.ただし $\vec{a}_{\mathrm{c} g}^{\mathrm{V}}$ が第 6 図に示すように，小さくて下向き，すなわち機体下方 $\left(z^{\mathrm{W}}\right.$ 方向）を中心とした所定の扇形領域に入る場合は, $z^{\mathrm{W}}$ 方 向が $\vec{a}_{\mathrm{c} g}^{\mathrm{V}}$ の方向になるようにする.これにより，機体上方 $\left(-z^{\mathrm{W}}\right.$ 方向) への所定值以内の慣性力を許容して機体の大 きなローリングを防ぐとともに，加速度の指令值への追従 を速くする .このようなローリング防止法は従来文献には 余り見られない.このときバンク角指令值 $\phi_{\mathrm{bc}}$ と弚の制御 偏差 $e_{\phi \mathrm{b}}\left(=\phi_{\mathrm{bc}}-\phi_{\mathrm{b}}\right)$ は, 第 6 図のようになる . 図におい

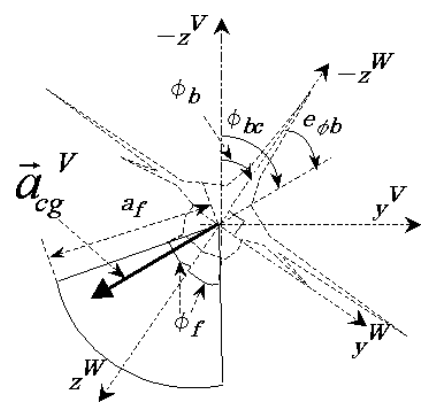

第 6 図 バンク角と扇形領域

て $, \phi_{\mathrm{f}}, a_{\mathrm{f}}$ は扇形領域を定める定数であり， $a_{\mathrm{f}}$ の值は航空 機に許容される $z^{\mathrm{B}}$ 方向の力 ( $\mathrm{G}$ フォース) から定める . 以上の議論から，

$$
\phi_{\mathrm{bc}}=\angle^{\left(-z^{\mathrm{V}}\right)}\left( \pm \vec{a}_{\mathrm{c} g}^{\mathrm{V}}\right)
$$

となる.ここで $\angle^{\left(-z^{\mathrm{V}}\right)}(\vec{a})$ は,$y^{\mathrm{V}} z^{\mathrm{V}}$ 平面において $-z^{\mathrm{V}}$ 方向を基準 (角度 0 ) としたときの任意のべクトル $\vec{a}$ の角 度を表わし, $y^{\mathrm{V}}$ 軸から $z^{\mathrm{V}}$ 軸への回転方向 $\left(x^{\mathrm{V}}\right.$ 軸に関し て右回り) を角度の正方向とする . (26) 式の複号は, ベク トル $\vec{a}_{\mathrm{c} g}^{\mathrm{V}}$ が第 6 図の扇形領域に入るとき負 , 入らないとき 正とする .

2.4 ロール, ピッチ, ヨーの角加速度指令值 $p_{\mathrm{c}}, q_{\mathrm{c}}, r_{\mathrm{c}}$ の計算 $p_{\mathrm{c}}$ はバンク角 $\phi_{\mathrm{b}}$ の $\mathrm{PD}$ (比例・微分) 制御の操 作量として，次式で求める.

$$
p_{\mathrm{c}}=K_{\mathrm{pP}} \cdot e_{\phi \mathrm{b} 1}+K_{\mathrm{pD}} \cdot \dot{e}_{\phi \mathrm{b} 1}
$$

ここで

$$
e_{\phi \mathrm{b} 1}=\left(\phi_{\mathrm{bc}}-\phi_{\mathrm{b}}\right) \cdot \min \left\{1, k_{\mathrm{a}}\left|\vec{a}_{\mathrm{c} g}\right|\right\}
$$

ただし $k_{\mathrm{a}}$ は適当な正の定数であり， $\left|\vec{a}_{\mathrm{c} g}\right|$ が小さいときは $\left|p_{c}\right|$ を小さして, ロール角の変動を抑えるために導入し た． $K_{\mathrm{pP}} ， K_{\mathrm{pD}}$ は制御ゲインであり，適当な定数とする． $\left(\phi_{\mathrm{bc}}-\phi_{\mathrm{b}}\right)$ の值については, $[-\pi, \pi]$ の範囲を超えたとき は $2 \pi$ を加算または減算してこの範囲に入れる.

つぎに $q_{\mathrm{c}}$ は, 必要加速度 $\vec{a}_{\mathrm{c}}^{\mathrm{V}}$ の揚力方向成分 $a_{\mathrm{cL}}$ を生 み出すように算出する $a_{\mathrm{cL}}$ は次式で求められる.

$$
a_{\mathrm{cL}}=\left|\vec{a}_{\mathrm{c}}^{\mathrm{V}}\right| \cos \left(\phi_{\mathrm{b}}-\mu_{\mathrm{ac}}^{\mathrm{V}}\right)
$$

ここで

$$
\mu_{\mathrm{ac}}^{\mathrm{V}}=\angle^{\left(-z^{\mathrm{V}}\right)}\left(\vec{a}_{\mathrm{c}}^{\mathrm{V}}\right)
$$

(29) 式や後述の (34) 式右辺において, 指令值 $\phi_{\mathrm{bc}}$ でなく 実際の値 $\phi_{\mathrm{b}}$ を用いる理由は, $a_{\mathrm{L}}$ や $r$ が指令值に近づく 速さが通常， $\phi_{\mathrm{b}}$ が $\phi_{\mathrm{bc}}$ に近づく速さよりはるかに速いた めである .

一方，横滑り角が小さいとき揚力方向加速度 $a_{\mathrm{L}}$ はほぼ

$$
a_{\mathrm{L}}=V_{\mathrm{a}} \cdot(q-\dot{\alpha})
$$

と表わされる.上式の $q$ を $q_{\mathrm{c}}$ に置き換えて上式右辺と (29) 
式右辺とを等号で結び，さらに $\dot{\alpha}$ を省く .すると $q_{\mathrm{c}}$ は

$$
q_{\mathrm{c}}=\frac{\left|\vec{a}_{\mathrm{c}}^{\mathrm{V}}\right| \cdot \cos \left(\phi_{\mathrm{b}}-\mu_{\mathrm{ac}}^{\mathrm{V}}\right)}{V_{\mathrm{a}}}
$$

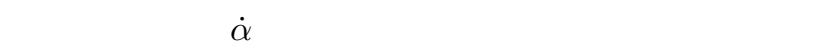
ションで制御が振動的になり制御性能が悪化した .このお もな原因は $q_{\mathrm{c}}$ から $\dot{\alpha}$ への伝達特性の時間遅れと思われる. そこで $\dot{\alpha} は$ 省き，省いたことによる影響は (23) 式で表わ されるフィードバック制御で除去することにした．

つぎに $r_{\mathrm{c}}$ は, 必要加速度の $y^{\mathrm{W}}$ 方向成分 $a_{\mathrm{c} y}^{\mathrm{W}}$ 発生に寄 与するためのものであり, 次式で求めるものとする .

$$
r_{\mathrm{c}}=k_{\mathrm{r}} \frac{a_{\mathrm{c} y}^{\mathrm{W}}}{V_{\mathrm{a}}}
$$

こニで

$$
a_{\mathrm{c} y}^{\mathrm{W}}=\left|\vec{a}_{\mathrm{c}}^{\mathrm{V}}\right| \cdot \sin \left(\mu_{\mathrm{ac}}^{\mathrm{V}}-\phi_{\mathrm{b}}\right)
$$

$k_{\mathrm{r}}$ は制御ゲインを表わし，通常は 1.0 に設定する。

以上求めた $p_{\mathrm{c}}, q_{\mathrm{c}}, r_{\mathrm{c}}$ の值については, 機体強度や飛行 性能を考慮して，適切な上下限制限を行う。

2.5 迎角, 横滑り角と $\mathrm{G}$ フォースの上下限制限 飛行 性能維持と安全確保のために, これらの值は所定の上下限 值以内に制限する必要がある. 迎角 $\alpha$ と G フォースの制 限は, $q_{\mathrm{c}}$ の值の修正により行い, 横滑り角 $\beta$ の制限は $r_{\mathrm{c}}$ の值の修正により行う.

まず迎角 $\alpha$ が所定の上限值 $\alpha_{\max }$ を超えないように， $q_{\mathrm{c}}$ の值を制限する方法はつぎのように表わされる「「 $\left\ulcorner e_{\alpha}=\right.$ $\left(\alpha_{\max }-\alpha\right)$ の值が所定の值 $\Delta_{\alpha}$ 以下のときは, $q_{\mathrm{c}}$ の值が 上限值 $q_{\mathrm{cmax}}$ を超えないようにする 」ここで

$$
\begin{aligned}
q_{\mathrm{cmax}}= & q_{\mathrm{c}(-1)}-K_{\alpha \mathrm{P}} \cdot \dot{\alpha} \cdot \Delta T \\
& +K_{\alpha \mathrm{I}} \cdot e_{\alpha} \cdot \Delta T
\end{aligned}
$$

$q_{\mathrm{cmax}}$ は， $\alpha$ の值が上限値になるように PI 制御するときの 操作量 $q_{\mathrm{c}}$ の値， $q_{\mathrm{c}(-1)}$ は $q_{\mathrm{c}}$ の前回値 (制御周期 $\Delta T$ だ け前の值) である. $K_{\alpha \mathrm{P}}, K_{\alpha \mathrm{I}}$ は制御ゲインであり，適当 な正定数に定める. $\alpha$ の下限值制限と横滑り角 $\beta$ の上下限 制限も，同樣の方法で行う.

つづいて Gフォース，すなわち機体に加わる $z^{\mathrm{B}}$ 方向の 力に対応する加速度 $a_{z}^{\mathrm{B}}$ が上下限值を超えないように， $q_{\mathrm{c}}$ の值を制限する方法を述べる．横滑り角が小さいとき $a_{z}^{\mathrm{B}}$ は次式で表わされる .

$$
a_{z}^{\mathrm{B}}=g \cos \theta \cdot \cos \phi+V_{\mathrm{a}} \cdot(q-\dot{\alpha}) \cos \alpha
$$

$a_{z}^{\mathrm{B}}$ の上下限値を $a_{z \max }^{\mathrm{B}}, a_{z \min }^{\mathrm{B}}$ と表わし，このときの $q_{c}$ の上限值 $q_{\mathrm{cmax}}$ は次式で表わすものとする.

$$
q_{\mathrm{cmax}}=\frac{a_{z \max }^{\mathrm{B}}-g \cos \theta \cdot \cos \phi}{V_{\mathrm{a}} \cos \alpha}+\dot{\alpha}
$$

$q_{\mathrm{c}}$ の下限值については, 上の “max” を “min”に置き換え て求める $q_{\mathrm{c}}$ の值はこれらの上下限値を超えないように修 正する .
2.6 Controller \#2 における制御方式 $p, q, r, V_{\mathrm{a}}$ の制御には, PID (比例・積分・微分) 制御則などの任意の 方式を適用可能である。たとえば速度 $V_{\mathrm{a}}$ の制御には，つ ぎのPI 制御則の適用が考えられる。

$$
T_{\mathrm{hc}}=K_{\mathrm{TP}} \cdot e_{\mathrm{va}}+\int K_{\mathrm{TI}} \cdot e_{\mathrm{va}} \mathrm{d} t
$$

ここで, $T_{\mathrm{hc}}$ はエンジン出力指令值， $e_{\mathrm{va}}$ は速度 $V_{\mathrm{a}}$ の制御 偏差, $K_{\mathrm{TP}}, K_{\mathrm{TI}}$ は制御ゲイン (定数) である.

$$
\text { 3. シミュレーション }
$$

F16 戦闘機を対象として，本稿で提案した制御のシミュ レーションを行った . 機体の運動方程式には, 文献 7) に記 載の非線形モデルを用い, 速度の目標値は $156[\mathrm{~m} / \mathrm{s}]$ で一 定，制御開始時の高度は海抜 $0[\mathrm{~m}]$ とした $\cdot p, q, r$ の制御 (姿勢制御) においては, エルロン, エレベータ, ラダーを

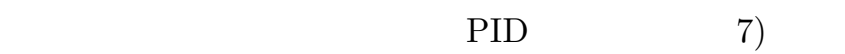
考にして構成し，横滑り角 $\beta$ の制御（目標值は 0 ），ロール ダンパ，ヨーダンパも設定した。速度 $V_{\mathrm{a}}$ の制御は (38) 式 に基づいて行った .第7〜10図に，航空機目標方向を大きく 変えたときのシミュレーションの一例を示す.第 7 図は制御 量, 弚の目標值, 速度 $V_{\mathrm{a}}$, バンク角 $\phi_{\mathrm{b}}$, ピッチ角速度 $p$ の 時間的変化を表わす. 時刻が $1[\mathrm{~s}] \rightarrow 5[\mathrm{~s}] \rightarrow 8[\mathrm{~s}] \rightarrow 12[\mathrm{~s}]$ と変 わるのに合わせて, 制御目標值 $\gamma_{c}$ が $0^{\circ} \rightarrow 90^{\circ} \rightarrow 90^{\circ} \rightarrow 0^{\circ}$ と変化し, 目標值 $\lambda_{\mathrm{c}}$ は, 時刻 $8[\mathrm{~s}]$ のときに $0^{\circ}$ から $90^{\circ}$ までステップ状に変化している.一方, 制御量 $\gamma$ は, 時刻 $7.5[\mathrm{~s}]$ のときに目標値の $90^{\circ}$ に到達し, 弚の瞬間に $\lambda$ と $\phi_{\mathrm{b}}$ は $0^{\circ}$ から $180^{\circ}$ に変化している.目標値 $\lambda_{\mathrm{c}}$ が $90^{\circ}$ に 変化後は, $\lambda$ は速やかに目標值に収束している．以上, $\lambda$, $\gamma$ ともに目標值変化に少し遅れて追従し, 目標値が一定に なった後は速やかに整定している。

時刻が 1〜 $5[\mathrm{~s}]$ 間と 8〜12 $[\mathrm{s}]$ 間では $\gamma_{\mathrm{c}}$ の変化速度が大 きいために, $\gamma$ の制御偏差か時間とともに大きくなってい るが, 別のシミュレーションで $\gamma_{\mathrm{c}}$ の変化速度が第 7 図の 0.5 倍以下のときは, 制御偏差は次第に小さくなり 0 に収 束した.一方, 速度 $V_{\mathrm{a}}$ は, 機体上昇開始直後にエンジン 出力が上限に達したため減少したが, 水平飛行に移行後は

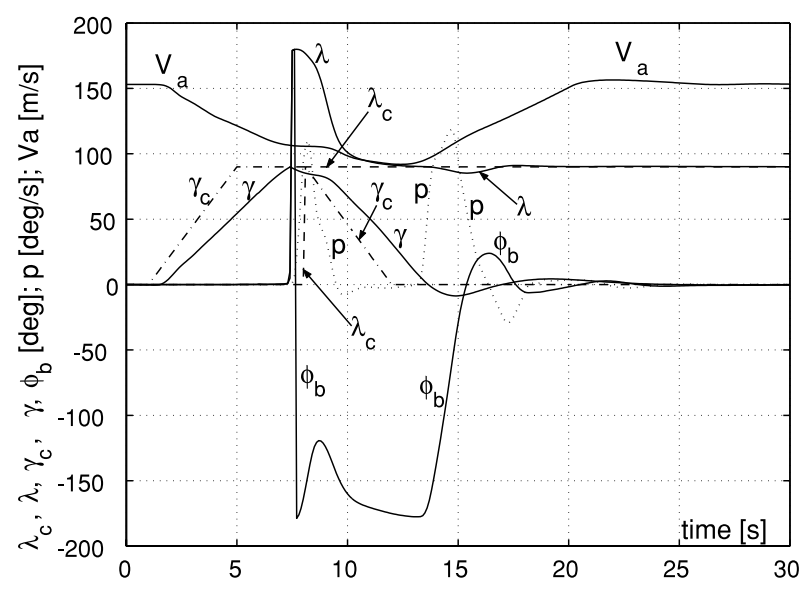

第 7 図 制御シミュレーションの一例 (1) 


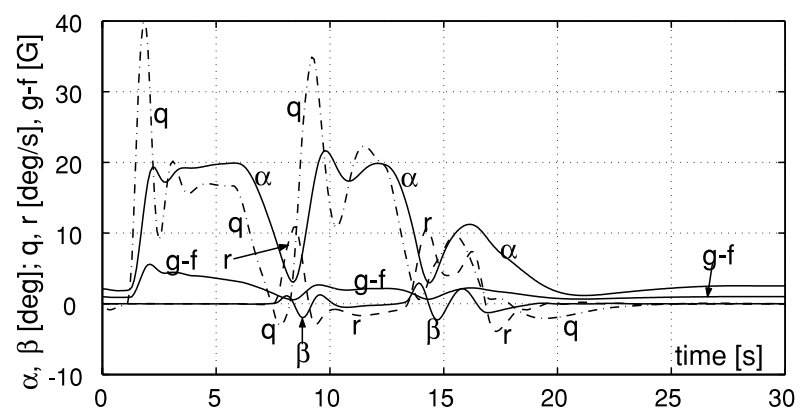

第 8 図 制御シミュレーションの一例 $(2)$

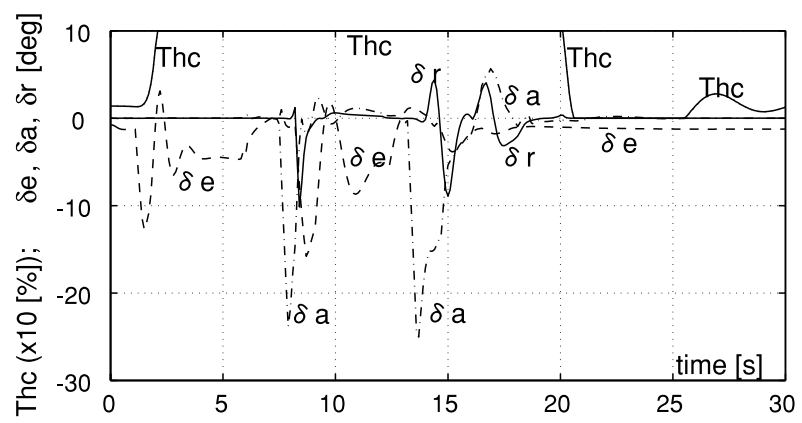

第 9 図 制御シミュレーションの一例 (3)

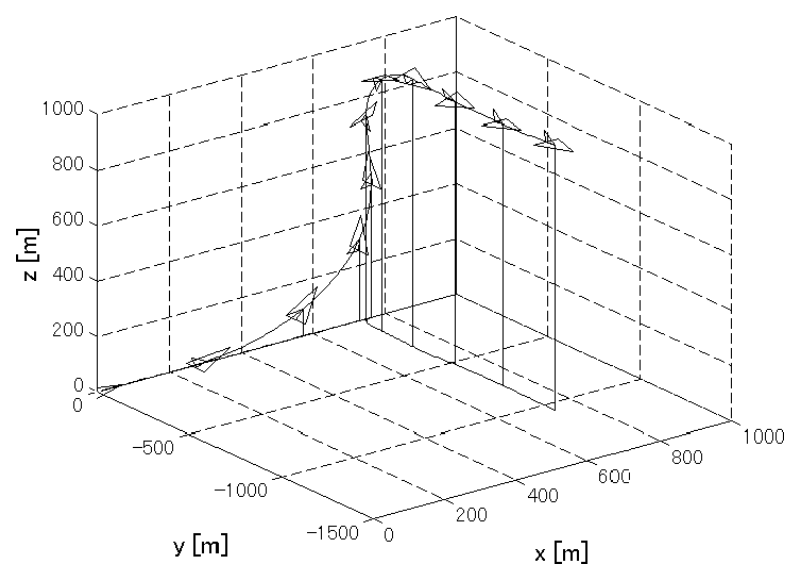

第10図 制御シミュレーションの一例 (4)

\section{目標値に復帰している.}

つぎの第 8 図は迎角 $\alpha$, 横滑り角 $\beta, \mathrm{G}$ フォース $\mathrm{g}-\mathrm{f}$ ， およびピッチとヨーの角速度 $(q, r)$ の時間的変化を示す. ここで迎角 $\alpha$, 横滑り角 $\beta$ および $\mathrm{g}-\mathrm{f}$ の範囲は光れ午れ， $-5^{\circ} \leftrightarrow 20^{\circ},-4^{\circ} \leftrightarrow 4^{\circ},-1 \leftrightarrow 9[\mathrm{G}]$ に制限した . 図よ り，これらの制限はほほ守られている.また時刻 2〜6 $[\mathrm{s}]$ と 9 13 [s] の間は $\alpha$ の值がほぼ上限になり，第 7 図にお いて $\gamma$ の制御偏差が次第に大きくなることの要因になって いることがわかる . $\alpha$ の上限値を大きくすると， $\gamma$ の制御
偏差は少し改善される反面 , バンク角の制御性が悪くなる つづいて第 9 図は, 航空機への制御入力 [エレベータ・ エルロン・ラダーの角度 $\left(\delta_{\mathrm{e}}, \delta_{\mathrm{a}}, \delta_{\mathrm{r}}\right)$, エンジン出力指令 值 $\left.T_{\mathrm{hc}}\right]$ の变化を示す. $T_{\mathrm{hc}}$ は $2 \sim 20[\mathrm{~s}]$ 間は $100 \%$ (上限 值)になっている。

最後の第 10 図は, 0 20 [s] 間のシミュレーションにお ける航空機の姿勢と飛行軌跡を表わす. 軌跡は「水平飛行 $\rightarrow$ 垂直上昇 $\rightarrow 90^{\circ}$ 右方向への水平飛行」と，指令通りに 变化している.

$\gamma_{\mathrm{c}}$ を $0^{\circ} \rightarrow-90^{\circ} \rightarrow 0^{\circ}$ と逆方向に変化させたシミュレー ションも, 以上のシミュレーションとほぼ同樣の結果とな つた。

\section{4. おわりに}

航空機の進行方向を制御する比較的簡易な方法について 述べた．本方式を用いれば，進行方向の指令值が上下 $90^{\circ}$ を含めた任意の方向に時々刻々変化する場合に，ほぼ好 な追従が可能である.オンライン制御計算において，機体 運動の逆システムは必要とせず, 空力微係数は用いない .

目標方向の変化速度が急激に変化するときは, 制御遅れ が避けられないが, 数秒先の目標方向が事前にわかってい る場合は，目標変化を予測した制御を取り入れることによ り，行き過ぎや遅れを抑えることは可能と思われる．

進行方向指令值を，空間内で与えられた目標経路に沿っ て飛行するように生成すれば，本方式により飛行経路制御 を実現することも可能と思われ，今後検討予定である .

最後に, 在学中にシミュレータの開発・検証に協力して いただいた, 帝京大学卒業生の斎藤, 篠原, 吉岡, 葛城, 浜 出, 松崎の各氏に感謝いたします。

\section{参 考 文 献}

1) 馬場順昭，宮本盛慈：与えられた経路のための飛行制御系，日本 航空宇宙学会誌, 38 (1990), pp. 494-501.

2) 馬場順昭, 高野博行, 佐野正樹 : 航空機の目標経路への誘導と制 御，第 12 回誘導制御シンポジウム, 1995, pp. 147-154.

3) Steharu-Alexe, I. and O'Shea, J.: Four-Dimensional Guidance of Atmospheric Vehicles, J. Guid. Control Dynam., 19 (1996), pp. $113-122$.

4) 高野博行, 越智信介, 馬場順昭 : アクロバット飛行の最適化につ いて, 第 38 回飛行機シンポジウム講演集，2000, pp. 93-96.

5) 芳谷直治 : 目標加速度ベクトルから求めたバンク角とピッチ角速 度指令值に基づいた，航空機の方位角・経路角制御，第 41 回飛行 機シンポジウム講演集 , 2003, 2C5.

6) G. ジェニングズ (伊里正夫・伊里由美 訳): 幾何再入門, 岩波書 店，東京，1996

7) Stevens, B. L. and Lewis, F. L.: Aircraft Control and Simulation, John Wiley \& Sons, New York, 1992. 